\title{
Penghidupan Berkelanjutan Rukun Nelayan Tanggulangin Kecamatan Klirong Kabupaten Kebumen
}

\section{Sustainable Livelihood Of Tanggulangin Fishing Community Klirong District Kebumen Regency}

\author{
Zulaikhah Fitri $^{1}$, Sugihardjo ${ }^{2}$, Agung Wibowo ${ }^{3}$ \\ ${ }^{1 *, 2,3}$ Fakultas Pertanian, Program Studi Penyuluhan dan Komunikasi Pertanian Universitas Sebelas Maret, \\ Surakarta
}

Korespondensi: zulaikhahfitri08@gmail.com

\begin{abstract}
ABSTRAK
Rukun Nelayan Tanggulangin selama ini masih bergantung pada hasil tangkapan ikan padahal sumber daya yang tersedia dapat dimanfaatkan dan dikelola dengan baik untuk meningkatkan penghidupan. Pendekatan penghidupan berkelanjutan dibutuhkan guna menentukan nelayan mempertahankan hidupnya. Penelitian ini bertujuan untuk mengkaji penghidupan berkelanjutan Rukun Nelayan Tanggulangin untuk dapat bertahan hidup. Penelitian ini menggunakan metode kualitatif deskriptif dan analisis data secara interaktif dan berlangsung secara terus menerus hingga data jenuh. Hasil penelitian menunjukkan penghidupan berkelanjutan yang dilakukan oleh Rukun Nelayan Tanggulangin melalui upaya mempertahankan sarana penangkapan ikan secara tradisional dan ramah lingkungan; mempertahankan modal sosial; memanfaatkan peluang mata pencaharian lain sesuai dengan sumber daya alam yang tersedia serta memberdayakan keluarga nelayan.
\end{abstract}

\section{Kata kunci : Berkelanjutan, Penghidupan, Rukun Nelayan}

\section{ABSTRACT}

Tanggulangin Fishing Community nowadays still depends on fish production, eventhough the available resources can be utilized and managed properly to improve livelihoods. A sustainable livelihood approach is needed to determine fisher survive. This study aims to examine the sustainable livelihoods of the Tanggulangin Fishing Community in order to survive. The study uses descriptive qualitative methods and interactive data analysis and continues until the data was saturated. The results shows the sustainable livelihoods was carried out by the Tanggulangin Fishing Community through maintaining traditional and environmentally friendly fishing facilities; maintaining social capital; take advantage of other livelihood opportunities in accordance with available natural resources and to empowering fisher family.

Keywords : Sustainable, Livelihood, Fishing Community 


\section{PENDAHULUAN}

Indonesia sebagai merupakan negara maritim dan kepulauan yang di dalamnya terkandung kekayaan hayati sumber daya ikan. Apabila potensi tersebut dikelola dengan baik, seharusnya dapat menyejahterakan masyarakat perikanan, khususnya nelayan sebagai pelaku utama dalam pembangunan perikanan. Bekerja sebagai nelayan merupakan salah satu mata pencaharian yang masih dipertahankan karena lebih cepat menghasilkan, meskipun profesi nelayan dirasa kurang memberikan kesejahteraan. Nelayan selalu menghadapi masalah ketidakpastian hasil tangkapan. Salah satu kendala yang dihadapi oleh nelayan adalah sumber daya laut bersifat akses terbuka (open access) dan milik bersama (common property), sehingga siapa saja yang menguasai atau memiliki modal dan sarana penangkapan adalah mereka yang mampu meningkatkan hasil tangkapan. Oleh sebab itu, penguasaan sumber daya dalam perikanan ditentukan oleh faktor pemilikan modal dan penguasaan teknologi (Wahyono et al, 2001).

Rukun Nelayan Tanggulangin merupakan komunitas atau kelompok nelayan yang berdomisili di wilayah pesisir Pantai Tanggulangin. Mereka masih menggunakan perahu dan alat penangkapan ikan tradisional serta ramah lingkungan sehingga tidak mempengaruhi keseimbangan sumber daya perikanan. Modal yang sedikit mempengaruhi proses produksi, pembelian alat tangkap, serta menghambat proses kerja, dan terbengkalainya kegiatan usaha nelayan. Nelayan yang hidup dengan tradisi melaut bersama mengharuskan penerapan sistem bagi hasil dan diperhadapkan dengan alokasi biaya operasional. Rukun Nelayan Tanggulangin merupakan kelembagaan nelayan yang dapat menampung aspirasi nelayan terkait kebijakan pemerintah serta memonitoring aset berupa sarana dan prasarana untuk melaut. Adanya kelembagaan ini,. mMembantu nelayan untuk mengelola aset penghidupannya, lebih terstruktur dan dapat menjalin hubungan dengan pemerintah/dinas terkait bantuan sarana dan prasarana penangkapan ikan, seperti yang telah dijelaskan melalui peraturan Direktur Jenderal Perikanan Tangkap nomor 4/PER-DJPT/2019.

Berdasarkan database DINLUTKAN Kabupaten Kebumen (2019), produksi ikan laut di TPI Tanggulangin yang merupakan TPI bagi Rukun Nelayan Tanggulangin menduduki posisi 4 terendah untuk volume produksi ikan dan posisi 3 terendah untuk nilai produksi ikan laut dari seluruh TPI di Kabupaten Kebumen. Hal ini disebabkan oleh 
banyaknya nelayan yang tidak melaut pada bulan-bulan tertentu. Pantai Tanggulangin belum memiliki pemecah ombak sehingga Rukun Nelayan Tanggulangin berangkat melaut tergantung pada gelombang air laut dan pergerakan angin.

Rukun Nelayan Tanggulangin sejauh ini masih memikirkan pada masa sekarang dan belum memperhatikan masa yang mendatang, sehingga penghidupannya bertumpu pada hasil tangkapan ikan yang tidak menentu (tergantung kondisi alam). Mereka masih bergantung pada sumber daya alam perairan yang dirasa cukup untuk memenuhi kebutuhan hidupnya. Padahal sumber daya lain di sekitar dapat dimanfaatkan dan dikelola guna menunjang penghidupannya. Hal yang patut menjadi perhatian adalah ketika sumber daya laut sebagai potensi daerah belum bisa dimanfaatkan dan dikelola dengan baik. Banyak faktor yang menyebabkan hal tersebut seperti pengelolaan potensi kelautan baik berupa aset, akses serta aktivitas yang dilakukan oleh Rukun Nelayan Tanggulangin.

Peneliti tertarik untuk meneliti bagaimana mereka dapat bertahan hidup dan upaya dalam mempertahankan penghidupannya dengan adanya aset yang terdapat di wilayah pesisir Pantai Tanggulangin. Oleh karena itu, perlu adanya pendekatan penghidupan berkelanjutan (sustainable livelihood) yaitu kegiatan yang dibutuhkan oleh setiap orang/masyarakat untuk menjalankan kehidupannya dengan menggunakan kapasitas/kemampuan serta kepemilikan sumber daya (asset) untuk mencapai tingkat kehidupan yang diharapkan (Chambers dan Conway, 1991). Pendekatan penghidupan berkelanjutan membantu Rukun Nelayan Tanggulangin dalam mengelola aset penghidupan yang dimiliki dan dapat diakses guna mempertahankan hidupnya di masa sekarang dan akang datang.

\section{METODE PENELITIAN}

Metode penelitian menggunakan pendekatan kualitatif deskriptif. Pemilihan lokasi dengan pertimbangan bahwa Rukun Nelayan Tanggulangin yang terdaftar di TPI Tanggulangin berada di Desa Tanggulangin Kecamatan Klirong Kabupaten Kebumen, memiliki usaha di bidang perikanan meliputi nelayan, pembudidaya, dan penambang pasir. Sesuai database DINLUTKAN Kab. Kebumen (2019), produksi ikan laut di TPI Tanggulangin cukup rendah karena banyak nelayan yang tidak melaut pada bulan 
tertentu. Sisi lain, pantai Tanggulangin belum memiliki pemecah ombak sehingga nelayan berangkat melaut bergantung pada pergerakan angin dan gelombang laut=

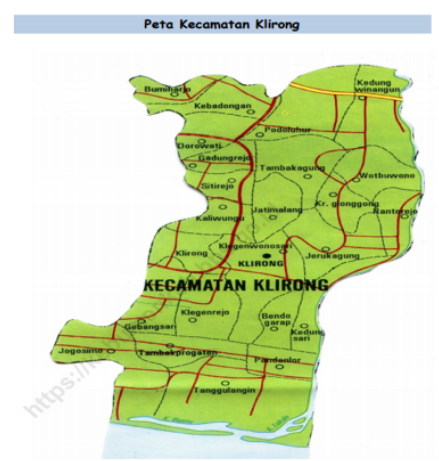

Gambar 1. Peta Kecamatan Klirong (BPS, 2019)

\section{Teknik Pengumpulan Data}

Informan dipilih secara snowball dengan purposive sampling yang berkaitan langsung maupun tidak langsung dengan penelitian. Informan diantaranya adalah Ketua, Pengurus dan Anggota Rukun Nelayan Tanggulangin; Penyuluh Perikanan Kecamatan Klirong/Sekretaris TPI Tanggulangin, Bidang Tangkap Dinas Kelautan dan Perikanan Kabupaten Kebumen/Ketua TPI Tanggulangin, Tenaga Harian Kerja TPI Tanggulangin/Ketua POKLAHSAR Tri Mina Sari serta perangkat Desa Tanggulangin, dan warga Desa Tanggulangin. Data diperoleh dengan teknik wawancara kualitatif (peneliti sebagai instrumen kunci, dapat menggali lebih dalam yang tersembunyi dari informan), observasi partisipan (terlibat dalam kegiatan yang dilakukan), dan dokumentasi (mendokumentasikan kegiatan kehidupan Rukun Nelayan Tanggulangin baik dari foto-foto ataupun berasal dari dokumen tertulis).

\section{Analisis Data}

Data yang diperoleh, dianalisis secara interaktif dan berlangsung terus menerus sampai tuntas sehingga datanya jenuh. Analisis interaktif menurut Miles dan Huberman dalam Sugiyono (2016), adalah reduksi data, penyajian data dan penarikan kesimpulan. Hasil analisis data kemudian divalidasi menggunakan triangulasi sumber dan teknik. Data dari beberapa sumber dideskripsikan, dan dikategorisasikan, mana pandangan yang sama, berbeda, dan mana yang spesifik. Teknik triangulasi sumber dipilih pada penelitian ini untuk membandingkan/mencek ulang derajat kepercayaan suatu informasi yang diperoleh 
melalui sumber yang berbeda. Teknik triangulasi dengan cara mengecek data kepada sumber yang sama dengan teknik yang berbeda, melalui wawancara, observasi, dan dokumentasi (Gambar 2, 3 dan 4).

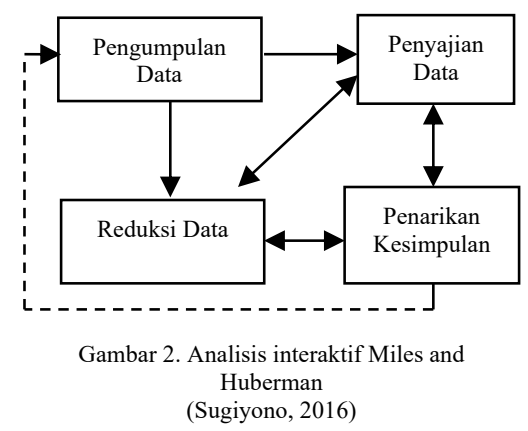

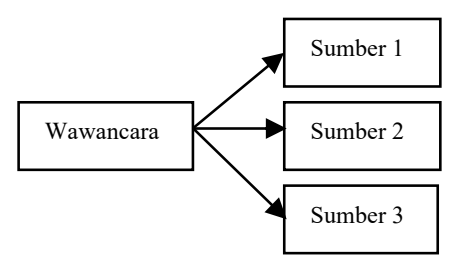

Gambar 3. Triangulasi sumber (Sugiyono, 2016)

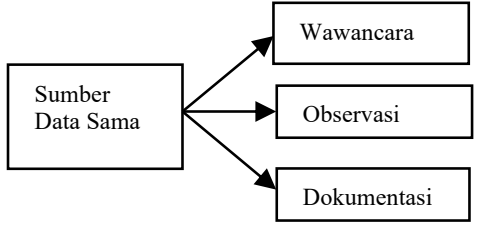

Gambar 4. Triangulasi teknik (Sugiyono, 2016)

\section{HASIL DAN PEMBAHASAN}

\section{Deskripsi Umum Lokasi Penelitian}

Secara geografis, Desa Tanggulangin merupakan salah satu desa pesisir di Kecamatan Klirong, Kabupaten Kebumen. Desa Tanggulangin memiliki luas wilayah daratan yaitu $509 \mathrm{Ha}$, laut 12 mil dari darat sejauh $3 \mathrm{~km}$, panjang garis pantai $3 \mathrm{~km}$ dan berada pada ketinggian $6 \mathrm{~m} / \mathrm{dpl}$ di atas permukaan laut. Pantai yang dekat dengan desa tersebut juga diberi nama Pantai Tanggulangin. Aset perikanan yang ada di desa dan sekitarnya menjadikan sebagian penduduknya memilih mata pencaharian sebagai nelayan.

Guna menunjang dalam bidang perikanan terdapat fasilitas bangunan yaitu TPI (Tempat Pelelangan Ikan) Tanggulangin diperuntukkan bagi nelayan. Nelayan yang terdaftar di TPI Tanggulangin selanjutnya disebut sebagai Rukun Nelayan Tanggulangin terdiri dari beberapa kelompok nelayan (beberapa desa). Jumlah kelompok nelayan ada 7 kelompok, setiap kelompok lebih dari 20 anggota.

Berdasarkan database DINLUTKAN Kabupaten Kebumen (2019), jumlah nelayan yang terdaftar di TPI Tanggulangin adalah 244 orang. Pantai Tanggulangin lebih terlihat sebagai laguna/rawa karena tepat berada di Muara Sungai Luk Ulo. Muara Luk Ulo ini digunakan sebagai tempat pemancingan populer di Kebumen, baik yang datang dari luar maupun dalam daerah Kebumen. Selain itu, sungai Luk Ulo menjadi tempat untuk sumber penghasilan bagi penambang pasir. 
ISSN : 2684-7051

\section{Kondisi Sosial Ekonomi}

Rukun Nelayan Tanggulangin selama ini hanya bergantung pada musim/alam sehingga hasil tangkapan ikan yang diperoleh dan pemasukan bagi TPI Tangulangin tidak menentu. Peningkatan hasil produksi ikan laut berada pada musim ikan melimpah sedangkan penurunan produksi ikan laut pada musim paceklik. Hal ini yang berpengaruh pada pendapatan yang tidak menentu. Umumnya Rukun Nelayan Tanggulangin melaut pada bulan Oktober-Maret atau musim dimana gelombang laut tidak tinggi sedangkan musim paceklik/tidak melaut pada bulan April-September dimana pergerakan angin dan gelombang laut tinggi serta sedikit ikan yang dapat ditangkap. Hal tersebut dapat dilihat pada Tabel 1 mengenai produksi ikan laut per bulan di TPI Tanggulangin.

Tabel 1. Produksi ikan laut per bulan di TPI Tanggulangin tahun 2019

\begin{tabular}{ccc}
\hline Bulan & Produksi (Kg) & Nilai (Rp) \\
\hline Januari & $2,764.80$ & $179,717,550.00$ \\
Februari & $4,180.00$ & $187,698,850.00$ \\
Maret & $4,218.70$ & $83,607,800.00$ \\
April & 58.20 & $4,350,600.00$ \\
Mei & - & - \\
Juni & - & - \\
Juli & - & - \\
Agustus & - & - \\
September & - & - \\
Oktober & 148.00 & $821,000.00$ \\
November & $3,726.22$ & $60,215,300.00$ \\
Desember & $3,510.10$ & $64,967,278.00$ \\
\hline Jumlah & $\mathbf{1 8 , 6 0 6 . 0 2}$ & $\mathbf{5 8 1 , 3 7 8 , 3 7 8 . 0 0}$ \\
\hline
\end{tabular}

Sumber: Data Sekunder, 2019

Rukun Nelayan Tanggulangin masih menggunakan sarana penangkapan tradisional dan ramah lingkungan yaitu perahu yang hanya berukuran 1 GT (mesin perahu 15 PK) dan jaring insang hanyut (driftnets) berukuran minimal 2 inch dan maksimal 6 inch. Alasan Rukun Nelayan Tanggulangin masih menggunakan sarana penangkapan tradisional dan ramah lingkungan karena modal yang dimiliki sedikit, jika menggunakan kapal yang lebih besar akan membutuhkan modal yang besar dan menyebabkan terbentuknya pemilik modal yang besar, sedangkan untuk nelayan kecil (tradisional) lama kelamaan akan tersisih padahal nelayan adalah salah satu mata pencaharian utama yang masih dipertahankan oleh Rukun Nelayan Tanggulangin. Jaring insang hanyut termasuk dalam alat tangkapan ikan yang ramah lingkungan berdasarkan klasifikasi statistik internasional standar FAO yang ramah lingkungan. Jaring insang hanyut disebut sebagai alat tangkap yang ramah lingkungan dan selektif. Arti dari ramah lingkungan karena 
dalam pengoperasiannya tidak mengakibatkan pencemaran dan kerusakan lingkungan. Pengertian selektif karena alat tangkap ini hanya menangkap ikan dengan ukuran tertentu tergantung besarnya ukuran mata jaring yang dipakai oleh alat tangkap dan bersifat pasif sehingga ikan yang tertangkap dengan sendirinya tanpa menggerus ke dasar lautan sehingga dapat meminimalkan hasil tangkapan yang belum layak tangkap berdasarkan ukurannya misalnya telur ikan, benur ataupun ikan-ikan kecil yang masih dapat tumbuh dan berkembang di habitat aslinya (laut).

Pendapatan yang tidak menentu dari Rukun Nelayan Tanggulangin berpengaruh terhadap bagaimana rumah tangga nelayan dalam memenuhi kebutuhan hidup. Upaya yang mereka lakukan antara lain dengan mencari sampingan pekerjaan lain di luar nelayan, mengikutsertakan anak/saudara (laki-laki) dan istrinya di bidang perikanan, dan sharing poverty (berbagi kemiskinan). Rukun Nelayan Tanggulangin sebagian besar mencari sumber penghasilan lain demi memenuhi kebutuhan hidup, tidak hanya bertumpu pada hasil tangkapan ikan tetapi dapat bersinergi dengan sumber penghasilan lain untuk meningkatkan penghidupan misalnya di bidang perikanan lain (tambak udang/ikan tawar), pertanian, peternakan, penambang pasir, buruh pasir, buruh bangunan d1l. Nelayan juga dapat bersinergi dengan anggota keluarga mereka untuk dapat membantu memenuhi kebutuhan rumah tangga.

Anak dan saudara (laki-laki) diikutsertakan dalam melaut setelah mereka lulus dari pendidikan terakhirnya (setingkat SMP/SMA atau berkisar umur 15-18 tahun). Tujuan keterlibatan anak dan saudara dalam melaut adalah mewariskan profesi nelayan dan membantu memenuhi kebutuhan penghidupannya. Tingkat pendidikan Rukun Nelayan Tanggulangin masih rendah, sebagian besar pendidikan terakhirnya adalah setingkat SD dan SMP, hanya beberapa yang berpendidikan SMA dan perguruan tinggi. Mereka yang ikut serta melaut atas keinginan sendiri setelah tamat pendidikan sekolahnya. Mereka yang sudah terbiasa dan merasa nyaman dalam melaut sulit untuk memikirkan kembali dalam meneruskan pendidikan ke jenjang lebih tinggi. Hal ini yang menjadikan anak dan saudara nelayan juga ikut mewariskan sebagai nelayan. Mereka bekerja sebagai nelayan karena lebih cepat menghasilkan dibandingkan dengan pekerjaan lain.

Istri-istri nelayan diikutsertakan dalam membantu memenuhi kebutuhan rumah tangga dengan tergabung dalam POKLAHSAR (Kelompok Pengolahan dan Pemasaran) 
ikan hasil tangkapan nelayan. Namun, POKLAHSAR dalam perkembangannya, belum sepenuhnya aktif $\overline{\bar{y}}$ dan masih bergantung pada musim ikan. Jika pada musim ikan mereka banyak memproduksi bahan olahan ikan tetapi pada musim paceklik hanya memproduksi sedikit bahkan tidak sama sekali karena ikan yang tersedia pada nelayan pun sedikit atau tidak ada. Tujuan nelayan mengikutsertakan istri mereka dalam POKLAHSAR adalah dapat memanfaatkan ikan berukuran kecil yang tidak laku dijual dapat diolah menjadi olahan pangan jadi yang kemudian dapat dipasarkan dan dijual menjadi suatu produk (keripik, bakso, ikan asin). Kegiatan POKLAHSAR dalam pengolahan ikan membantu menggerakkan pertumbuhan ekonomi rumah tangga nelayan. Pengolahan ikan yang membutuhkan keterampilan dan telaten untuk nelayan sendiri merupakan kegiatan yang dapat dialihkan pada istri (perempuan). Hal ini juga memberikan kegiatan lain pada istriistri nelayan tidak hanya sebagai ibu rumah tangga tetapi dapat bekerja untuk membantu menambah penghasilan rumah tangga mereka.

Rukun Nelayan Tanggulangin dalam memenuhi penghidupan juga membutuhkan bantuan sesama. Saling berbagi antarnelayan juga dilakukan pada nelayan yang kesulitan secara finansial, mereka akan membantu dalam meminjamkan uangnya pada nelayan lain yang membutuhkan. Saling berbagi kemiskinan (sharing poverty) juga dapat dilihat dari nelayan yang pada saat melaut memperoleh tangkapan banyak terkadang ada yang mengadakan syukuran sehingga dapat memberikan rasa kebersamaan (nelayan dapat merasakan kebahagiaan yang sama dengan syukuran tersebut/ikut merasakan euforianya).

Hubungan antar nelayan juga terlihat pada modal sosial yang dimiliki oleh Rukun Nelayan Tanggulangin, antara lain tradisi, kepercayaan, kehidupan beragama, kebiasaan bekerja dan jejaring untuk menyeimbangkan mereka dalam penghidupan. Modal sosial merupakan gambaran kemudahan dalam jaringan sosial yang dimanfaatkan rumah tangga baik formal maupun informal yang menjadi tumpuan untuk dapat bertahan hidup. Modal sosial menunjukkan bagaimana rumah tangga memiliki interaksi dengan masyarakat lain di lingkungan sosialnya. Modal sosial dianggap mampu meningkatkan kepercayaan (mutual trust) dan mengurangi biaya bekerja secara bersama-sama (DFID, 1999). Modal sosial tradisi, kepercayaan, kebiasaan bekerja dan kehidupan beragama membantu nelayan untuk mengetahui bagaimana dalam melakukan penangkapan ikan. Jejaring Rukun Nelayan Tanggulangin dan POKLAHSAR juga turut membantu nelayan untuk 
meningkatkan penghidupan dengan mengelola sumber daya yang dimiliki dan dapat diakses.

\section{Karakteristik Rukun Nelayan Tanggulangin}

Rukun Nelayan Tanggulangin dalam menangkap ikan di laut tergantung pada musim/pergerakan angin/gelombang laut. Hal ini dikarenakan di Pantai Tanggulangin belum memiliki pemecah ombak sehingga tidak setiap saat dapat melaut. Berbeda halnya dengan nelayan yang ada di daerah barat pantai selatan Kebumen yang sudah memiliki pemecah ombak sehingga mereka dapat melaut kapan saja dan TPI dapat beroperasi kapanpun karena nelayan dapat melaut sehari penuh bahkan bermalam di lautan. Rukun Nelayan Tanggulangin hanya dapat melaut hingga sore hari/setengah hari (berangkat pukul 05.00 pagi hingga sore hari) dan umumnya melaut pada bulan Oktober-Maret atau musim dimana gelombang laut tidak tinggi sedangkan musim paceklik/tidak melaut pada bulan April-September dimana pergerakan angin dan gelombang laut tinggi serta sedikit ikan yang dapat ditangkap. Hal ini juga menyebabkan TPI Tanggulangin sering beroperasi pada musim melaut karena hasil tangkapan ikan nelayan yang banyak sedangkan pada musim paceklik terkadang TPI tidak beroperasi.

Penangkapan ikan yang tergantung pada musim menyebabkan Rukun Nelayan Tanggulangin memiliki pekerjaan sampingan agar tetap bertahan hidup. Menurut Wahyono dkk (2001), dalam hal eksploitasi sumber daya perikanan bersifat milik bersama (common property) dan dilakukan secara bebas (open access), tanpa ada batasbatas wilayah yang jelas seperti pada sumber daya pertanian. Tanpa ada batas yang jelas ini menyebabkan nelayan tidak dapat menentukan hasil tangkapan (tergantung alam) sehingga hasil yang diperoleh tidak menentu.

Sampingan pekerjaan yang dilakukan antara lain dalam bidang perikanan lainnya, pertanian, peternakan dan lain-lain. Nelayan yang memiliki sampingan pekerjaan di bidang perikanan lain disebut nelayan mandiri. Mereka memiliki modal yang lebih dan keterampilan untuk melakukan usaha di bidang perikanan budidaya ikan/udang. Usaha perikanan budidaya ikan di Desa Tanggulangin adalah ikan tawar (nila, lele, gurameh) dengan menggunakan air tawar sedangkan untuk budidaya yang menggunakan air laut adalah budidaya udang (vanamei). Nelayan mandiri dalam melakukan budidaya 
seringnya adalah udang (vanamei) dibandingkan dengan budidaya ikan tawar (kadangkadang). Nelayan mandiri di Rukun Nelayan Tanggulangin berjumlah sekitar 15-20 orang. Mereka memiliki pekerjaan sampingan dikarenakan jika pada musim tidak melaut dapat mengembangkan usaha tersebut untuk memenuhi kebutuhan rumah tangga. Tambak yang digunakan untuk usaha perikanan tersebut adalah milik sendiri, dan ada yang dikelola sendiri maupun disewakan pada nelayan lain. Sistem sewa menerapkan sistem bagi hasil dimana pemilik hanya menerima uang sewa yang dibagi rata beberapa orang dalam kegiatan budidaya tetapi tidak melakukan budidaya. Luas lahan tambak yang digunakan untuk budidaya perikanan masing-masing berukuran 40x50 m².

Berbeda dengan nelayan yang tidak termasuk mandiri, sebagian besar memilih diversifikasi pekerjaan seperti bertani, beternak sapi/ayam, buruh bangunan, menambang pasir atau menjadi buruh pasir (pengangkut pasir). Bagi nelayan yang memiliki lahan berupa ladang/tegalan mereka memilih bertani yaitu menanam tanaman produktif misalnya palawija (jagung, singkong, dan kacang panjang), pepaya, sayuran (cabai, terong, pare). Selain bertani, nelayan juga beternak sapi atau ayam yang dilakukan di pekarangan rumah mereka. Ternak sapi atau ayam dijadikan sebagai tabungan (jaga-jaga) untuk kebutuhan mendesak.

Nelayan yang tidak memiliki lahan untuk usaha menambah sumber penghasilan sebagai penambang pasir atau pengangkut pasir, yang melakukan pekerjaan tersebut adalah buruh nelayan. Buruh nelayan ini adalah nelayan yang hanya menjalankan perahu dari pemilik modal dan tidak memiliki lahan sendiri untuk dapat melakukan mata pencaharian lain serta kurangnya keterampilan dalam melakukan usaha.

\section{Penghidupan Berkelanjutan Rukun Nelayan Tanggulangin}

Penghidupan berkelanjutan menurut Chambers and Conway (1991) didefinisikan sebagai suatu penghidupan yang meliputi kemampuan atau kecakapan (kapabilitas), aset (sumber daya) dan kegiatan yang dibutuhkan untuk sarana hidup. Kapabilitas merujuk pada kemampuan melakukan fungsi-fungsi dasar tertentu dan apa yang mampu dilakukan seseorang, misalnya kemampuan untuk mengatasi stres dan guncangan; mampu menemukan serta memanfaatkan peluang mata pencaharian; termasuk mendapatkan akses dan menggunakan layanan dan informasi; melakukan tinjauan ke masa depan; 
bereksperimen dan berinovasi; bersaing dan berkolaborasi dengan orang lain; memanfaatkan kondisi dan sumber daya baru. Penghidupan berkelanjutan Rukun Nelayan Tanggulangin antara lain sebagai berikut:

1. Mempertahankan sarana penangkapan tradisional dan ramah lingkungan

Rukun Nelayan Tanggulangin masih menggunakan sarana penangkapan tradisional yaitu perahu tempel 1 GT (15 PK) yang tidak dapat menjangkau daerah tangkapan ikan yang luas, sehingga berpengaruh pada penghasilan yang diperolehnya dari mata pencaharian nelayan. Alat tangkapan yang digunakan juga ramah lingkungan (jaring insang hanyut) dimana alat tangkap tersebut menjaring ikan pelagis dan demersal secara pasif (ikan yang terjaring) sehingga tidak menggerus sampai dasar laut dan tidak menjaring sumber daya ikan yang kecil-kecil (masih dapat tumbuh dan berkembang) agar tetap menjaga keseimbangan ekosistem laut. Ramah lingkungan dilakukan agar tetap mempertahankan potensi yang ada untuk masa depan (tidak merusak lingkungan) selain memang hanya potensi ikan pelagis dan demersal yang dapat ditangkap.

Keberlanjutan lingkungan ditandai dengan Rukun Nelayan Tanggulangin masih menggunakan perahu 1 GT (tradisional) dan alat tangkap yang ramah lingkungan meskipun mengorbankan hasil tangkapan ikan yang banyak dengan menggunakan sarana penangkapan modern. Mereka beranggapan bahwa hasil tangkapan ikan sudah diatur oleh sang pencipta. Fokus mereka adalah bagaimana mereka dapat mengelola sumber daya perikanan secara bijak untuk menyediakan penghidupan di masa mendatang (generasi penerus).

2. Mempertahankan modal sosial

Mempertahankan modal sosial bagi Rukun Nelayan Tanggulangin adalah suatu hal yang diperhatikan untuk dapat menyelaraskan penghidupan. Modal sosial membantu nelayan dalam mengontrol aset penghidupan yang dimiliki, tidak hanya dapat meningkatkan penghidupan tetapi juga dapat menyelaraskan dengan penggunaan yang bijak dan kelestarian lingkungan. Modal sosial antara lain tradisi, kepercayaan, kehidupan beragama, kebiasaan bekerja serta jejaring. Tradisi (larungan, pertunjukkan wayang kulit, grebeg suran dan pengajian) bertujuan sebagai bentuk ungkapan rasa syukur kepada Tuhan serta berguna untuk saling menjaga dan 
melindungi nelayan serta mengharapkan keberkahan ikan yang berlimpah. Kepercayaan yang dipercayai mengenai musim melaut untuk membantu nelayan dalam penangkapan ikan (tergantung pada kepercayaan masing-masing individunya) misalnya kepercayaan orang meninggal di laut/sungai pertanda musim ikan/datangnya ikan, nelayan akan berlomba-lomba ke laut untuk menangkap ikan; kepercayaan dalam menangkap ikan haruslah sopan, sabar dan ikhlas dengan harapan tidak terjadi kejadian yang buruk menimpa mereka dalam melaut; kepercayaan melakukan perawatan perahu dan alat tangkap dengan ritual di teras Pantai Tanggulangin setiap Kamis Wage sore dengan harapan perahu tetap aman saat melaut selain dengan selalu dibersihkan setiap pulang melaut dengan air laut. Kebiasaan bekerja untuk mengetahui daerah tangkapan ikan (bau amis saat masuk laut pertanda ikan sudah dekat/menemukan daerah tangkapan ikan sedangkan keluarnya lumbalumba di sekitar perahu menandakan bahwa di bawahnya terdapat banyak ikan). Kehidupan beragama membantu nelayan dalam hasil tangkapan yang diperoleh dan kapan dapat melaut, misalnya setiap hari adalah hari baik bagi Rukun Nelayan Tanggulangin sehingga pantangan yang dihadapi hanya pergerakan gelombang laut yang tinggi. Hal ini dikarenakan sebagian besar nelayan disini adalah muslim (beragama islam) sehingga kepercayaan terhadap hal mistis sudah banyak ditinggalkan. Akan tetapi, untuk kepercayaan yang ada tergantung pada masingmasing individu nelayan yang mempercayainya (tidak semua nelayan). Tradisi tetap dilaksanakan karena bentuk penghormatan kepada alam yang telah memberikan kelimpahan sumber daya.

Modal sosial lainnya adalah adanya jejaring. Jejaring Rukun Nelayan Tanggulangin membantu nelayan sebagai wadah aspirasi bagi nelayan untuk mengatasi permasalahannya serta memonitoring sarana prasarana penangkapan ikan termasuk pengajuan bantuan kepada pemerintah. Jejaring POKLAHSAR membantu nelayan dalam mengelola aset penghidupan (hasil tangkapan ikan dan istri nelayan) untuk mengolah hasil tangkapan ikan dengan melibatkan istri nelayan dalam memenuhi kebutuhan rumah tangganya.

Modal sosial disesuaikan dengan konteks kelembagaan maupun norma yang berlaku dalam suatu kelompok masyarakat (Oktavia, 2017). Modal sosial adalah 
hubungan yang terjadi dan diikat oleh suatu kepercayaan (trust), saling pengertian (mutual understanding), dan nilai-nilai bersama (shared value) yang mengikat anggota kelompok untuk membuat kemungkinan aksi bersama dapat dilakukan secara efisien dan efektif (Cahyono dan Adhiatma, 2012). Modal sosial Rukun Nelayan Tanggulangin dengan harapan agar tetap menjaga lingkungan ekosistem perairan laut dengan tidak menggunakan sarana penangkapan yang terlarang/berbahaya dan dapat merusak ekosistem laut. Oleh karena itu, mereka tetap mempertahankan sarana penangkapan ikan yang ramah lingkungan dan tetap mematuhi peraturan yang berlaku. Peraturan yang berlaku misalnya dengan tetap menggunakan jaring insang hanyut yang ukurannya sesuai dengan Permen KP No 59/2020 (2 inch) agar tidak menangkap ikan yang kecil sehingga dapat tumbuh berkembang di habitatnya; tidak menangkap hewan dan alat tangkap yang dilarang;

3. Memanfaatkan peluang mata pencaharian lain sesuai dengan sumber daya alam yang tersedia

Rukun Nelayan Tanggulangin dalam memenuhi penghidupannya juga memanfaatkan sumber daya alam yang tersedia misalnya adanya lahan untuk penggunaan tambak udang (vanamei)/ikan tawar (lel, nila, gurameh), sektor pertanian yaitu bercocok tanam palawija (jagung, singkong, kacang panjang), lahan pekarangan rumah yang digunakan untuk beternak sapi/ayam, dan sungai Luk Ulo untuk penambang pasir. Mereka memanfaatkaan mata pencaharian lain guna meningkatkan penghidupan yang tidak menentu apalagi pada musim paceklik bagi nelayan. Mata pencaharian utama mereka adalah nelayan tetapi karena penghasilan yang tidak menentu maka mereka tetap memanfaatkan mata pencaharian lain agar tetap dapat bertahan hidup baik pada musim ikan maupun musim paceklik.

4. Memberdayakan anak, saudara, dan istrinya

Istri-istri nelayan diikutsertakan dalam membantu memenuhi kebutuhan rumah tangga dengan tergabung dalam POKLAHSAR (Kelompok Pengolahan dan Pemasaran) ikan hasil tangkapan nelayan. Anak dan saudara (laki-laki) diikutsertakan dalam melaut setelah mereka lulus dari pendidikan terakhirnya (setingkat SMP/SMA atau berkisar umur 15-18 tahun). Tujuan keterlibatan anak dan saudara dalam melaut adalah mewariskan profesi nelayan dan membantu memenuhi kebutuhan 
penghidupannya. Diharapkan untuk anak dan saudara tidak hanya dapat meneruskan dalam penangkapan ikan tetapi dapat memiliki keterampilan lain di bidang perikanan agar mampu mengolah dan mengelola potensi daerahnya. Jika tidak dapat meneruskan pada jenjang sekolah, tetapi dapat memperoleh pengetahuan dan keterampilan dari pengalaman dengan orang yang ahli/sudah memiliki keahlian atau mengikuti pelatihan yang diadakan oleh dinas/pemerintah terkait dengan perikanan. Adanya hal tersebut maka tidak hanya akan mewariskan mata pencaharian nelayan tetapi juga meningkatkan penghidupan dengan adanya inovasi baru agar dapat menjadikan sumber penghidupan baru sebagai sumber penghasilan tambahan. Anak dan saudara diberdayakan agar tidak mengalami hal sama yang terjadi pada orang tuanya untuk menuju penghidupan yang lebih baik dan sejahtera.

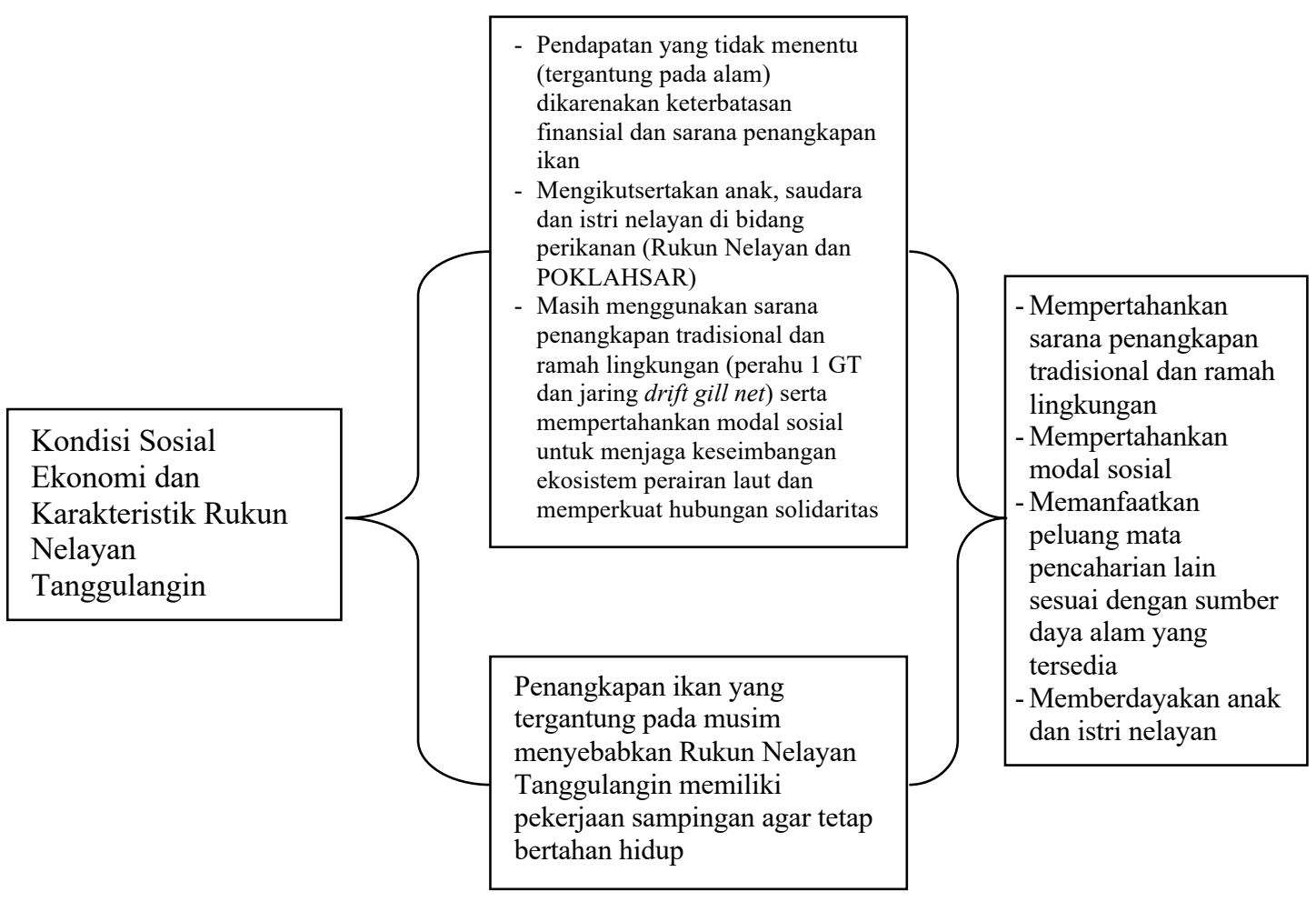

Gambar 5. Skema penghidupan berkelanjutan Rukun Nelayan Tanggulangin Kecamatan Klirong Kabupaten Kebumen 
ISSN : 2684-7051

\section{KESIMPULAN DAN SARAN}

Berdasarkan hasil penelitian dan pembahasan maka dapat disimpulkan sebagai berikut:

1. Penghidupan berkelanjutan yang dilakukan oleh Rukun Nelayan Tanggulangin melalui upaya mempertahankan sarana penangkapan ikan secara tradisional dan ramah lingkungan; mempertahankan modal sosial; memanfaatkan peluang mata pencaharian lain sesuai dengan sumber daya alam yang tersedia serta memberdayakan anak, saudara dan istri nelayan.

2. Penghidupan berkelanjutan melalui upaya mempertahankan sarana penangkapan ikan secara tradisional dan ramah lingkungan dapat memberikan keberlanjutan lingkungan dengan tidak merusak ekosistem perairan laut serta penggunaan yang bijak (menaati peraturan dan tatanan yang ada) dan sesuai dengan kebutuhan.

3. Penghidupan berkelanjutan melalui upaya mempertahankan modal sosial juga dapat memberikan keberlanjutkan lingkungan dengan masih menjalankan tradisi, kepercayaan, kebiasaan bekerja dan kehidupan beragama, sedangkan hubungan antarsesama dan jejaring dapat memperkuat hubungan solidaritas Rukun Nelayan Tanggulangin.

4. Penghidupan berkelanjutan dengan memanfaatkan peluang mata pencahariaan lain dapat memberikan keterampilan lain dan meningkatkan penghidupan=, disamping pemberdayaan anak, saudara dan istri nelayan di bidang perikanan agar dapat tetap meneruskan mata pencaharian untuk generasi mendatang, serta meningkatkan penghidupan melalui pengelolaan aset perikanan.

\section{DAFTAR PUSTAKA}

Badan Pusat Statistik Kabupaten Kebumen. 2019. Kecamatan Klirong dalam angka 2019. diakses dari https://kebumenkab.bps.go.id/publication/download.html?nrbvfeve=NWNmYjVlO TU5ZGZkYTc5NTIxMzhkNDZi\&xzmn=aHR0cHM6Ly9rZWJ1bWVua2FiLmJw cy5nby5pZC9wdWJsaWNhdGlvbi8yMDE5LzA5LzI2LzVjZmI1ZTk1OWRmZGE 3OTUyMTM4ZDQ2Yi9rZWNhbWF0YW4ta2xpcm9uZy1kYWxhbS1hbmdrYS0y MDE5Lmh0bWw\%3D\&twoadfnoarfeauf=MjAyMS0wMy0wNiAxMzo0NDoyNQ $\% 3 \mathrm{D} \% 3 \mathrm{D}, 24$ November 2020. 
Cahyono, B., dan Adhiatma A. 2012. "Peran modal sosial dalam peningkatan kesejahteraan masyarakat petani tembakau di Kabupaten Wonosobo". Proceedings of Conference in Business, Accounting and Management (CBAM), 1(1): 131-144.

Chambers, R., dan Conway, G.R. 1991. Sustainable rural livelihoods: practical concepts for the 21st century. IDS Discussion Paper 296, diakses dari http://publications.iwmi.org/pdf/H_32821.pdf, 24 November 2020.

DFID. 1999. Sustainable livelihoods guidance sheets. Department for International Development, diakses dari http://www.livelihoods.org/, 24 November 2020.

Dinas Kelautan dan Perikanan Kabupaten Kebumen. 2019. Database Dinas Kelautan dan Perikanan Kabupaten Kebumen. Draft, diakses dari file://E:/Senam/dinlutkan.kebumenkab.go.id.210420-2.pdf, 24 November 2020.

Oktavia, R Yoserizal. 2017. "Livelihood Nelayan Tradisional Danau Singkarak Nagari Guguak Malalo Kecamatan Batipuh Selatan Kabupaten Tanah Datar”. JOM FISIP, $4(1), 1-14$.

Peraturan Direktur Jenderal Perikanan Tangkap nomor 4/PER-DJPT/2019. Petunjuk Teknis Bantuan Sarana Penangkapan Ikan pada Direktorat Jenderal Perikanan Tangkap. Draft, diakses dari https://kkp.go.id/an-component/media/upload-gambar pendukung/DJPT/2019/Perdirjen\%20No\%204\%20Th\%202019\%20ttg\%20Petunju k\%20Teknis\%20BSPI.pdf, tanggal 24 November 2020.

Peraturan Menteri Kelautan dan Perikanan Republik Indonesia nomor 59/PERMEN$\mathrm{KP} / 2020$. Jalur penangkapan ikan dan alat penangkapan ikan di wilayah pengelolaan perikanan negara Republik Indonesia dan laut lepas. diakses dari https://kkp.go.id/djpt/artikel/25590-peraturan-menteri-kelautan-dan-perikanannomor-59-permen-kp-2020, 24 November 2020.

Saragih, S., Jonatan, L., Afan, R. 2007. Kerangka penghidupan berkelanjutan sustainable livelihood framework, diakses dari https://www.zef.de/fileadmin/user_upload/2390_SL-Chapter1.pdf, 24 November 2020.

Scoones, I. 1998. Sustainable rural livelihoods: A framework for analysis. Working $\begin{array}{llll}\text { Paper } & \text { No. } & \text { diakses dari }\end{array}$ https://www.staff.ncl.ac.uk/david.harvey/AEF806/Sconnes1998.pdf, on 24 November 2020.

Sugiyono. 2016. Memahami penelitian kualitatif. Bandung: Alfabeta CV.

Wahyono, A, et al. 2001. Pemberdayaan masyarakat nelayan. Yogyakarta: Penerbit Media Pressindo. 